\title{
Teetering on a liver's edge: a case report highlighting clinical decision-making in thrombocytopenia
}

\author{
Adam Yan $^{1,2^{*}} \mathbb{D}$, Laura Erdman ${ }^{1}$, Lillian Sung ${ }^{2}$ and Stacey Bernstein ${ }^{1}$
}

\begin{abstract}
Background: This report illustrates the importance of a detailed history and physical exam and careful analysis of hematologic parameters when diagnosing ITP. This case demonstrates that even with subtle deviations from typical ITP findings one must promptly reevaluate the diagnosis. This case also highlights the importance of peripheral smear review by an expert in pediatric hematopathology.

Case presentation: A previously healthy 10 year-old Asian boy presented with 2 months of easy bruising. Review of systems was negative for any constitutional symptoms. On examination, he appeared well but had numerous large ecchymoses. He had no appreciable lymphadenopathy or splenomegaly. The liver was palpable $1.5 \mathrm{~cm}$ below the costal margin. A complete blood count (CBC) showed: platelets $=17 \times 109 / \mathrm{L}$, hemoglobin $=128 \mathrm{~g} / \mathrm{L}$, white blood cell count $=5.43 \times 109 / \mathrm{L}$, and neutrophils $=1.63 \times 109 / \mathrm{L}$. A blood smear was reported as normal. Urate was $370 \mathrm{umol} / \mathrm{L}$ and lactate dehydrogenase $(\mathrm{LDH})$ was $803 \mathrm{U} / \mathrm{L}$. The child was admitted with a presumptive diagnosis of immune thrombocytopenic purpura (ITP) and treated with intravenous immunoglobulin. The following day, the blood smear was reviewed by a hematopathologist who identified blasts. A bone marrow aspiration (BMA) confirmed the diagnosis of precursor B-cell acute lymphoblastic leukemia.

Conclusion: In children presenting with suspected ITP, leukemia should always be considered. A BMA was historically performed on all patients with presumed ITP to rule out leukemia. In 2011, the American Society of Hematology (ASH) stopped recommending routine BMA in patients suspected of having ITP. ASH advises in cases with unusual findings on history, physical examination or CBC, it is reasonable to perform a BMA. Our patient had mild hepatomegaly, which may have qualified him for a BMA. He also had an elevated LDH and urate, which are not listed as criteria for BMA by ASH but were considered atypical for ITP by the clinical team. A literature search did not reveal any primary data assessing these markers.

While corticosteroids are a first line treatment in ITP, they must be reserved for when clinicians are confident that the patient does not have leukemia. Steroid administration prior to diagnosing leukemia results in delayed diagnosis and may increase the risk of complications and decrease survival.
\end{abstract}

Keywords: Immune thrombocytopenic purpura, Acute lymphoblastic leukemia, Thrombocytopenia, Bone marrow analysis

\footnotetext{
* Correspondence: adam.yan@sickkids.ca

${ }^{1}$ Department of Paediatrics, The Hospital for Sick Children, 555 University Avenue, Toronto, ON M5G 1X8, Canada

${ }^{2}$ Department of Hematology and Oncology, The Hospital for Sick Children,

Toronto, Canada
}

(c) The Author(s). 2019 Open Access This article is distributed under the terms of the Creative Commons Attribution 4.0 International License (http://creativecommons.org/licenses/by/4.0/), which permits unrestricted use, distribution, and reproduction in any medium, provided you give appropriate credit to the original author(s) and the source, provide a link to the Creative Commons license, and indicate if changes were made. The Creative Commons Public Domain Dedication waiver (http://creativecommons.org/publicdomain/zero/1.0/) applies to the data made available in this article, unless otherwise stated. 


\section{Background}

Thrombocytopenia is one of the most common hematologic abnormalities encountered in pediatrics [1]. Thrombocytopenia is defined as a platelet count less than $150 \times 10^{9} / \mathrm{L}$ irrespective of age [1]. The clinical manifestations of thrombocytopenia include petechiae, purpura, gingival bleeding, epistaxis, menorrhagia, gastrointestinal bleeding, hematuria and central nervous system hemorrhage. The mechanisms of thrombocytopenia include diminished platelet production, shortened platelet life span, platelet sequestration and platelet loss or dilution (Table 1) [1].

\section{Case presentation}

A previously healthy, 10-year old male, Asian child presented to the emergency department with a two-month history of easy bruising. No episodes of mucocutaneous bleeding or petechiae were reported, other than one brief episode of self-limited epistaxis 2 weeks prior to presentation. There was no antecedent history of a viral illness, immunizations, drug exposure, recent travel or known sick contacts.

Review of systems was negative for any constitutional symptoms including bone pain, fevers, night sweats, anorexia, or weight loss. There was no family history of bleeding disorders, childhood malignancy, or autoimmune conditions.

On initial examination the child was afebrile, and appeared well. He had good energy and color. He had numerous large ecchymoses over the bony prominences of his shoulders and elbows, and he had several ecchymoses on his shins. He had no appreciable lymphadenopathy or splenomegaly. The liver was palpable approximately $1.5 \mathrm{~cm}$ below the right costal margin. The remainder of his physical exam was within normal limits.

Bloodwork was done in the emergency department. An initial complete blood count showed: platelets $=17 \times$ $10^{9} / \mathrm{L}$, hemoglobin $=128 \mathrm{~g} / \mathrm{L}$, white blood cell count $=$ $5.43 \times 10^{9} / \mathrm{L}$, lymphocytes $=2.29 \times 10^{9} / \mathrm{L}$, and neutrophils $=1.63 \times 10^{9} / \mathrm{L}$. A blood smear was reported as normal pending final hematopathologist review. Urate was $370 \mathrm{umol} / \mathrm{L}$ (normal $=100-277$ ) and lactate dehydrogenase $(\mathrm{LDH})$ was $803 \mathrm{U} / \mathrm{L}$ (normal $=432-700)$. Calcium, phosphate, potassium, creatinine, PTT and INR were all within normal limits. A chest radiograph showed no mediastinal mass or hilar adenopathy.

The child was admitted to hospital with a presumptive diagnosis of immune thrombocytopenic purpura (ITP). A hematology consult was requested. Therapeutic options were discussed. Given the concern for possible leukemia due to the palpable liver, elevated urate and elevated $\mathrm{LDH}$, the recommended course of action was intravenous immunoglobulin (IVIG)
Table 1 Differential diagnosis of thrombocytopenia

\begin{tabular}{|c|c|}
\hline \multirow{4}{*}{$\begin{array}{l}\text { A) Diminished Platelet } \\
\text { Production }\end{array}$} & -Marrow infiltration \\
\hline & -Marrow injury \\
\hline & -Infection \\
\hline & $\begin{array}{l}\text {-Genetic syndromes } \\
\text { (rare) }\end{array}$ \\
\hline \multirow{11}{*}{$\begin{array}{l}\text { B) Shortened Platelet } \\
\text { Life Span } \\
\text {-Immune Mediated } \\
\text {-Nonimmune Mediated }\end{array}$} & $\begin{array}{l}\text {-Immune } \\
\text { thrombocytopenic } \\
\text { purpura (ITP) }\end{array}$ \\
\hline & $\begin{array}{l}\text {-Neonatal alloimmune } \\
\text { thrombocytopenia }\end{array}$ \\
\hline & -Infection \\
\hline & $\begin{array}{l}\text {-Heparin induced } \\
\text { thrombocytopenia }\end{array}$ \\
\hline & $\begin{array}{l}\text {-Drug or vaccine } \\
\text { induced }\end{array}$ \\
\hline & $\begin{array}{l}\text {-Systemic } \\
\text { autoimmune } \\
\text { disease }\end{array}$ \\
\hline & $\begin{array}{l}\text {-Disseminated } \\
\text { intravascular } \\
\text { coagulation }\end{array}$ \\
\hline & $\begin{array}{l}\text {-Hemolytic uremic } \\
\text { syndrome }\end{array}$ \\
\hline & $\begin{array}{l}\text {-Thrombotic } \\
\text { thrombocytopenic } \\
\text { purpura }\end{array}$ \\
\hline & $\begin{array}{l}\text {-Major surgery } \\
\text { or trauma }\end{array}$ \\
\hline & -Infection \\
\hline \multirow{5}{*}{$\begin{array}{l}\text { C) Platelet Sequestration } \\
\text { or Pooling }\end{array}$} & -Hypersplenism \\
\hline & $\begin{array}{l}\text {-Kasabach-Merritt } \\
\text { phenomenon }\end{array}$ \\
\hline & $\begin{array}{l}\text {-Chronic liver or } \\
\text { storage } \\
\text { disease }\end{array}$ \\
\hline & $\begin{array}{l}\text {-Portal vein } \\
\text { thrombosis }\end{array}$ \\
\hline & $\begin{array}{l}\text {-Von Willebrand } \\
\text { disease (type } 2 \mathrm{~B} \\
\text { and platelet- } \\
\text { type) }\end{array}$ \\
\hline D) Platelet dilution & $\begin{array}{l}\text {-Massive transfusion } \\
\text { of packed red } \\
\text { blood cells } \\
\text { or whole blood }\end{array}$ \\
\hline
\end{tabular}

therapy and avoidance of corticosteroids. Post IVIG therapy, the platelets rose from 17 to $58 \times 10^{9} / \mathrm{L}$.

The following day, the peripheral blood smear was reviewed by a hematopathologist who identified the presence of blasts. Flow cytometry of the peripheral blood showed $12 \%$ blasts which were positive for CD10, CD19 and CD20, and a bone marrow aspiration confirmed the diagnosis of precursor B-cell acute lymphoblastic leukemia (ALL). The child was transferred to the 
oncology service for further evaluation and treatment, including a spinal tap. He was classified as having high risk central nervous system 2 ALL based on age and presence of blast cells in his CSF. Chemotherapy was initiated as per the Children's Oncology Group protocol AALL1131.

\section{Discussion and conclusion}

ITP can be classified based on the duration of thrombocytopenia. If the thrombocytopenia resolves within 12 months of onset it is classified as acute ITP and if it persists beyond 12 months it is classified as chronic ITP. Acute ITP is the most common cause of pediatric thrombocytopenia, affecting 5/100,000 children annually [1]. ITP is an autoimmune disorder characterized by immunologic destruction of platelets resulting in isolated thrombocytopenia in an otherwise well looking child without lymphadenopathy or hepatosplenomegaly [2]. The median age of presentation with ITP is 69 months [3]. The incidence of ITP peaks between 2 and 5 years of age with a second smaller peak in adolescents [4]. Primary ITP is defined as a platelet count less than $100 \times 10^{9} / \mathrm{L}$ in the absence of other causes or disorders that may cause thrombocytopenia [5]. Alternatively ITP may occur secondary to other autoimmune disorders (e.g., systemic lupus erythematosus, anti-phospholipid syndrome, Evans syndrome), viral infections (e.g., cytomegalovirus, hepatitis c, varicella zoster, human immunodeficiency virus) [5] or drugs (e.g., carbamazepine, quinine, and vancomycin) $[2,6]$.

In children presenting with suspected ITP, leukemia should be considered in the differential diagnosis. Although leukemia is classically associated with hematopoietic abnormalities beyond isolated thrombocytopenia, a bone marrow evaluation was historically performed on all patients with a presumed diagnosed of ITP to rule out leukemia prior to starting therapy. However, a number of retrospective studies called this practice into question [7, 8]. A review of 2239 children enrolled in two Pediatric Oncology Group acute lymphoblastic leukemia clinical trials showed that only 1 child presented with isolated thrombocytopenia, who had no blast cells on the blood smear, hemoglobin $>110 \mathrm{~g} / \mathrm{L}$ and an absolute neutrophil count $>1.5 \times 10^{9} / \mathrm{L}$. On physical examination, that child had marked hepatosplenomegaly, and thus was unlikely to be misclassified as typical ITP [7]. Subsequently, a review of confirmatory bone marrow analyses performed in 322 children presenting with typical features of acute ITP found zero cases of leukemia [8].

In 2011, the American Society of Hematology (ASH) revised its position statement on ITP, no longer recommending routine bone marrow evaluation in patients suspected of having typical ITP [5]. Both ASH and the American Association of Pediatrics (AAP) advise that in the case of unusual findings on history or physical examination such as fevers, weight loss, fatigue, bone pain, lymphadenopathy or hepatosplenomegaly, or unusual hematologic findings such as abnormal white or red blood cell counts, it is reasonable to perform a bone marrow examination [5, 9]. While ITP is more in children between 2 and 5 years of age and in adolescents, there is no recommendation to alter your diagnostic work-up for children presenting with what appears to be ITP at an atypical age [4].

Our patient had mild hepatomegaly, which may have qualified him for a bone marrow examination even if the peripheral smear was negative. He also had an elevated LDH and urate, which are not listed as criteria for bone marrow evaluation by the ASH or AAP guidelines but were considered as atypical for ITP by the clinical team caring for this patient. Some experts have recommended bone marrow examination if the LDH and urate are elevated in pediatric ITP [9]. However, a literature search did not reveal any primary data assessing these serum markers A recent study in adult patients, showed that urate is commonly elevated in patients with ITP [10]. Further work is needed to understand the significance of a high LDH and urate in pediatric ITP.

The initial management of ITP can include both observation and pharmacologic therapies. Between 80 and 90\% of ITP is self-limited, with patients making a full and permanent recovery within 12 months without any treatment [11]. Children over the age of 10 have an increased risk of progressing to chronic ITP with $47.3 \%$ having a platelet count $<150 \times 10^{9} / \mathrm{L} 6$ months after diagnosis [4]. Patients with platelet counts below $10-20 \times 10^{9} / \mathrm{L}$ are at increased risk for significant bleeding and this often prompts clinicians to offer pharmacologic interventions to raise the platelet count expeditiously. Initial pharmacologic options include IVIG or a short course of oral corticosteroids [5]. Costs, risk of bleeding and parental preferences factor into decision making [12].

While corticosteroids are one of the first line pharmacologic agents in ITP, they must be reserved for cases where clinicians are confident that the patient does not have leukemia. Steroid administration prior to the diagnosis of leukemia results in delayed diagnosis and may increase the risk of complications and decrease eventfree survival [13].

In our case, the patient presented to a quaternary care pediatric hospital with excellent access to laboratory technology and specialists. Recognition of atypical features consisting of mild hepatomegaly, and unexplained elevation of LDH and urate prompted clinicians to recommend IVIG and not corticosteroids as the initial treatment.

This report illustrates the importance of a detailed history and physical exam and careful analysis of presenting hematologic parameters when diagnosing ITP. Even 
subtle deviations from findings in typical ITP should prompt clinicians to reevaluate the diagnosis. This case also highlights the importance of peripheral smear review by an expert in pediatric hematology/oncology to ensure that blast cells are not missed. In this case, careful review ensured that the patient was fully investigated and did not receive steroids. It is important to emphasize that bone marrow analysis is not required for cases of typical ITP.

\section{Abbreviations}

AAP: American Association of Pediatrics; ALL: Acute lymphoblastic leukemia; ASH: American Society of Hematology; BMA: Bone marrow aspirate;

CBC: Complete blood count; ITP: Immune thrombocytopenic purpura;

IVIG: Intravenous immunoglobulin; LDH: Lactate dehydrogenase (LDH)

\section{Acknowledgements}

Not applicable.

\section{Authors' contributions}

$\mathrm{AY}$ is the resident who saw this patient from hematology, and wrote the first draft of the manuscript. LE is the resident who initially saw the patient, and helped with the manuscript. LS is the attending Oncologist who managed the patient after the diagnosis of leukemia was made and edited the manuscript. SB is the General Pediatrics attending physician who managed this patient during this admission and edited the manuscript. All authors read and approved the final manuscript.

\section{Funding}

The author(s) received no financial support for the research, authorship, and/ or publication of this article.

\section{Availability of data and materials}

We do not have any raw data supporting our findings.

Ethics approval and consent to participate

Ethics approval was not needed for this study. Consent to participate was obtained from the family of the patient described in the case.

\section{Consent for publication}

Consent to publish was obtained in writing from the father of the patient described in the case.

\section{Competing interests}

The authors declare that they have no competing interests.

Received: 20 March 2019 Accepted: 28 October 2019

Published online: 06 November 2019

\section{References}

1. Buchanan G. Thrombocytopenia during childhood: what the pediatrician needs to know. Peds Rev. 2017;26(11):401-9.

2. Bromberg ME. Immune thrombocytopenic purpura-the changing therapeutic landscape. N Engl J Med. 2006;355(16):1643-5.

3. Evim MS, Baytan B, Gunes AM. Childhood immune thrombocytopenia: long term follow up data evaluated by the criteria of the international working group on immune thrombocytopenic purpura. Turk J Hematol. 2014;31:32-9.

4. Zeller B, Rajantie J, Hedlund-Treutiger I, et al. Childhood idiopathic thrombocytopenic purpura in the Nordic countries: epidemiology and predictors of chronic disease. Acta Paediatr. 2005:94(2):178.

5. Neunert C, Lim W, Crowther M, et al. The American Society of Hematology 2011 evidence-based practice guidelines for immune thrombocytopenia. Blood. 2011;117(16):4190-207.

6. Richard H, Aster MD, Bougie DW. Drug-induced immune thrombocytopenia. NEJM. 2007;357:580-7.

7. Dubansky SA, Boyett JM, Falletta J, et al. Isolated thrombocytopenia in children with acute lymphoblastic leukemia: a rare event in a pediatric oncology group study. Pediatrics. 1989;84:1068-71.
8. Calpin C, Dick P, Poon A, Feldman W. Is bone marrow aspiration needed in acute childhood idiopathic thrombocytopenic purpura to rule out leukemia? Arch Pediatr Adolesc Med. 1998;152:345-7.

9. Chu YW, Korb J, Sakamoto KM. Idiopathic thrombocytopenia Purpura. Peds Rev. 2000;21(3):96-104.

10. Dal MS, Karakus A, Aydin BB, Ekmen MO, Ulas T, Ayyildiz A. Serum uric acid and inflammation in patients with immune thrombocytopenic purpura: preliminary results. Eur Rev Med Pharmacol Sci. 2015;19:4385-9.

11. Blanchette V, Bolton-Maggs P. Childhood immune thrombocytopenic purpura: diagnosis and management. Hematol Oncol Clin North Am. 2010; 24(1):249-73.

12. Beck CE, Boydell KM, Stasiulis E, et al. Shared decision making in management of children with newly diagnosed immune thrombocytopenia. J Pediatri Hematol Oncol. 2014;36(7):559-65.

13. Gatineau-Saillant S, Buchbinder N, Callat MP, et al. Steroid intake before leukemia diagnosis impairs outcomes in childhood acute lymphoblastic leukemia. Arch Peds. 2013;20(4):341-7.

\section{Publisher's Note}

Springer Nature remains neutral with regard to jurisdictional claims in published maps and institutional affiliations.

\section{Ready to submit your research? Choose BMC and benefit from:}

- fast, convenient online submission

- thorough peer review by experienced researchers in your field

- rapid publication on acceptance

- support for research data, including large and complex data types

- gold Open Access which fosters wider collaboration and increased citations

- maximum visibility for your research: over $100 \mathrm{M}$ website views per year

At BMC, research is always in progress.

Learn more biomedcentral.com/submissions 